Review Article

www.ijrap.net

\title{
AN OVERVIEW ON ANDROGRAPHIS PANICULATA (BURM. F.) NEES
}

Ghosh Kumar Benoy, Datta Kumar Animesh*, Mandal Aninda, Dubey Kumari Priyanka and Halder Sandip Department of Botany, Cytogenetics, Genetics and Plant Breeding Section, University of Kalyani, Kalyani - 741235, West Bengal, India

Received on: 11/08/12 Revised on: 17/10/12 Accepted on: 01/11/12

\author{
*Corresponding author \\ E-mail: dattaanimesh@gmail.com \\ DOI: 10.7897/2277-4343.03610 \\ Published by Moksha Publishing House. Website www.mokshaph.com \\ All rights reserved.
}

\section{ABSTRACT}

Andrographis paniculata (Burm. F.) Nees (Family: Acanthaceae) commonly known as Kalmegh (King of Bitters) is an important plant species in Ayurvedic medicine (prominent in 26 Ayurvedic formulations). An overview is conducted in the species considering all essential aspects namely, therapeutic uses, synonyms, common names, distribution, habitat, soil condition, cultivation, harvest, post harvest and storage, plant description, reproductive biology, cytological aspects, cytogenetical study, molecular genetics, extraction and detection of phytochemicals, assay, phytochemistry, insecticidal activity, clinical trials, contraindications and drug interactions, clinical implications, regulatory mechanism, in vitro studies and mutational studies to provide unabridged repository of references to researchers for its effective biological utilization.

Keywords: Andrographis paniculata; kalmegh; overview

\section{INTRODUCTION}

Andrographis paniculata (Burm. F.) Nees (Family: Acanthaceae) commonly known as Kalmegh (English name: King of Bitters) is an annual herb ${ }^{1}$ possessing immense therapeutic uses (mostly used parts are roots, leaves and aerial part of mature twig). The species is also reported to be perennial shrub ${ }^{2}$. It is native to India and Sri Lanka. An overview on $A$. paniculata covering nearly all essential aspects are documented in the text with an objective to provide knowledge for its proper utilization in human welfare and future exploration in the field of genetics and breeding for improvement.

\section{Therapeutic Uses}

A. paniculata is prominent in 26 Ayurvedic formulations as evidenced from Indian Pharmacopoeia; while, in Traditional Chinese Medicine it is an important "cold property" herb used to release body heat in fever ${ }^{3}$. The species is well explored therapeutically and effectively used as immunostimulant ${ }^{4}$ and for asthma, gonorrhea, piles $^{5}$, dysentery and dyspepsia ${ }^{6}$, blood purification ${ }^{7}$, influenza $^{8}$, gastric complaints, diarrhea ${ }^{9}$, pharyngitonsillitis $^{10}$, fever ${ }^{11}$, loss of scalp hair ${ }^{12}$, snake bite $^{13}$, myocardial ischemia ${ }^{14}$, common cold ${ }^{15}$, diabetes ${ }^{16}$, respiratory tract infections ${ }^{17}$, jaundice ${ }^{18}$ amongs others. The species also possesses antiulcerogenic ${ }^{19}$, antityphoid $^{20}$, anti snake venom ${ }^{21}$, antiplatelet aggregation $^{22}$, anti $\mathrm{HIV}^{23}$, antimalarial ${ }^{24}$, antifertility ${ }^{25}$, anti-inflamatory ${ }^{26}$ and antihyperglycemic ${ }^{27}$ properties.

Bioeffectivity of the species against phytopathogens (bacteria - Erwinia caratovora, Pseudomonas marginales, $P$. syringae, $P$. aeruginosa and Xanthomonas compestris; fungi - Acremonium strictum, Alternaria alternata, Aspergillus flavus, Bipolaris bicolor, Cladosporium herbarum, Curvularia lunata, Fusarium oxysporum, Pencillium expansum, Rhizoctonia solani, Tiarosporella phaseolina and Ustilago maydis) was noted from methanolic (95\%), chloroform (80\%) and hexane $(65 \%)$ extracts $^{3}$. Ethanolic extract of the leaves of $A$. paniculata was reported to inhibit growth of Escherichia coli and Staphylococcus aureus ${ }^{28}$; while, methanolic extract was effective against Proteus vulgaris ${ }^{29}$. Komwatchara ${ }^{30}$ and Rassameemasmaung $^{31}$ reported that $A$. paniculata has inhibitory effect against Porphyromonas gingivalis. Prajjal et $a .^{32}$ reported significant antimicrobial activity of aqueous extract of the species containing andrographolide and arabinogalactan proteins. Roy et al. ${ }^{33}$ also assessed the anti-microbial activity from inhibition zones, minimum inhibitory concentration (MIC) and minimum bactericidal concentration (MBC) values of $A$. paniculata extracts (chloroform and chloroform $+\mathrm{HCl}$ ) on four gram positive bacteria (Staphylococcus aureus, Bacillus subtilis, Enterobacter faecalis, S. epidermidis) as well as five gram-negative bacteria (Escherichia coli, Pseudomonas aeruginosa, Klebsiella pneumoniae, Salmonella typhimurium, Enterobacter cloacae) and suggested the utility of the species in development of novel broad spectrum antimicrobial agents.

\section{Synonyms}

Andrographis paniculata Wall ex. $\mathrm{Nees}^{34}$, Justicia latebrosa Russell ex Wall., J. paniculata Burm. f., J. stricta Lam. Ex Steud. ${ }^{35}$.

\section{Common Names}

Kalmegh, Kalafath, Kan-jang, Alui, Charita, Cherota, Chiraita, Cheretta, Kariyat, Green chiretta, Halviva, Kreat, Sinta, Rice bitters, Sambilata, Sambiloto, Andrographidis, $\mathrm{Kraut}^{36-41}$.

\section{Distribution}

Widely found and cultivated in tropical and subtropical Asia, south-east Asia and India ${ }^{37}$. The species is also reported from different phytogeographical and edaphic zones of China, America, West Indies and Christmas Island in Indian Ocean ${ }^{42}$. 


\section{Habitat}

The herb is found in a variety of habitat viz. plains, hill slopes $^{42}$, waste lands ${ }^{43}$, farms, dry or wet lands ${ }^{44}$, sea shore and even in the road side.

\section{Soil Condition}

The plant grows well in all types of soil which explains its wide distribution. It grows in soil types where almost no other plant can be cultivated, particularly 'serpentine soil', which is relatively high in metals such as aluminum, copper and zinc ${ }^{45}$. However, soil that is flooded or wet throughout the year may be avoided for its cultivation ${ }^{46}$. The species was also observed to grow luxuriously in mild humid locations with tropical temperature and high rainfall $^{34,47}$. Vijaya et $a l^{48}$ recommended the use of vermicompost coirpith for the reclamation of soils from industrial sites for the cultivation of $A$. paniculata in a small scale nursery.

\section{Cultivation}

Cultivation experiments were reported by different authors, namely, Zhou ${ }^{43}$, Nandi ${ }^{49}$, Gupta and Srivastava ${ }^{50}$, Muniramappa et ll $^{44}$ amongs others and they were of the opinion that in general $A$. paniculata prefers sunny condition and is raised from seeds. The seedlings raised in nursery beds should be transplanted to field at a distance of $60 \mathrm{~cm} \times 30 \mathrm{~cm}$ with 1 to 3 irrigations during the day periods particularly at flowering stage. In India the seeds of the species are sown in the months of May - June, flowers during August - November and the whole plant starts maturing during February - March. Maximum harvest of total diterpene lactones was noted at blooming from the aerial part.

\section{Harvest}

The best harvesting period of $A$. paniculata leaves ${ }^{51}$ is at 3-5 months old or at $50 \%$ blossom whereupon the highest quantity of active lactone compound was found followed by final harvesting after next 2-3 months, with an yield of 2-3 ton per hectare (fresh weight) or $0.5-1$ tons per hectare (dried weight).

\section{Post Harvest and Storage}

After harvest, the plants were cleaned and dried (cutting the plant into pieces) in hot air oven at $46^{\circ} \mathrm{C}$ to $50^{\circ} \mathrm{C}$ for 8 hours or until properly dried. The dried plant parts were stored in airless plastic bags and kept in clean cool place but not more than a year or otherwise there may be a decrease (upto 25\%) in quantity of total diterpene lactone ${ }^{52}$.

The stability of andrographolide was determined using a heat-accelerated experiment to reveal a $2^{\text {nd }}$ order kinetics of degradation and the rate constant of decomposition was determined to be $6.58 \times 10^{-6} \mathrm{~d}^{-1}$ at $25^{\circ} \mathrm{C}^{53}$.

\section{Plant Description}

The plant species is described on the basis of seeds (obtained from Govt. Medicinal Plant Garden, Narendrapur, West Bengal, India) sown in the experimental field of Dept. of Botany, University of Kalyani (22 $2^{\circ} 99^{\prime} \mathrm{N}, 88^{\circ} 45^{\prime} \mathrm{E}$, elevation 48 feet above mean sea level, sandy loamy soil, organic carbon- $0.76 \%$, soil $\mathrm{pH}$ 6.85). Voucher specimen deposited in the Herbarium, Dept. of Botany, University of Kalyani, Docket No. - AP01.
Annual branched herb (Figure 1); stem tetrangular, slightly winged, solid, woody, glabrous, green (31264 color confirmed from British Atlas of Colour, $9^{\text {th }}$ Edt., 2007); leaves opposite decussate, simple, $6.0-10.0 \mathrm{~cm}$ long and $3.5-5.0 \mathrm{~cm}$ wide, acute to acuminate at apex, entire at margin, often recurved at maturity, cuneate at base, herbaceous, unicostate reticulate with 5 to 6 pairs of usually alternate pinnate secondaries, glabrous on both surface, green (31264) to bottle green (31264) and often with copper shade (84351) coloration above at edge especially during flowering, petiolate; petioles slender 0.4 - $0.5 \mathrm{~mm}$ long, glabrous, greenish (31260); exstipulate; inflorescence paniculate cyme, both axillary and terminal; upper 5 to 6 axils with peduncles; peduncles 3.0 to $5.0 \mathrm{~cm}$ long, tetrangular, angles hairy along the four ridges; hairs dentate to scabrid, glabrescent at maturity, green (31264); bractiate, bracts 2 , opposite decussate, linear oblong to lanceolate, lower larger, upper smaller, 2.0 to $3.0 \mathrm{~mm}$ long and 0.5 to $1.0 \mathrm{~mm}$ wide, often hairy, green (31264), persistant; secondary peduncles 2.0 to $3.0 \mathrm{~cm}$ long alike to primary peduncle; bracts of secondary peduncles alike to primary peduncles; flowers complete, bisexual, hypogynous, irregular (zygomorphic), pentamerous, pedicillate; pedicels tetrangular, 2.0 to $3.0 \mathrm{~mm}$ long with glandular hairs, dull green (31258) often enlarged up to fruit, $2 \mathrm{~mm}$ long; sepals 5, linear dentate with glandular hairs; calyx tube turbinate with glandular hairs on the outer surface, corolla two lipped about $9.0 \mathrm{~mm}$ to 10.0 $\mathrm{mm}$ long, color pinkish violet (64220), hairy on the outer surface more towards posterior lobe and apex; posterior lip oblong, hooded over the anterior lip; anterior lip 3 lobed, median lobe larger broad, lateral smaller, outer surface with glandular hairs, glabrous within, having purple (64312) oval spot on the median lobe within and two purple (64312) lines to each lateral lobe within (Figure 2); corolla tube narrowed $5.0 \mathrm{~mm}$ long (Figure 3); androecium - stamens 2; filaments declinate, epipetalous, alternipetalous, pubescent throughout and more bristly at the base of anther attachment, whitish (00016) with purple (64312) lines; anther 2 celled oblong, dark (Figure 3) purple (643221); gynoecium 2, syncarpous; ovary superior, oblong, slightly 2 lobed, many ovules per chamber in axile placentation, glandular hairy throughout; style 1, terminal, purple (64312), glabrous; stigma shortly 2 fid; fruits simple, dry dehiscent, capsules laterally flat with 2 distinct lobes, marked by central depression along the septation (Figure 4), $12.0 \mathrm{~mm}$ to $17.0 \mathrm{~mm}$ long and $2.0 \mathrm{~mm}$ to $3.5 \mathrm{~mm}$ wide, spinous at the apex, narrowed at base, dull brown (44035) color at maturity; dehiscent loculicidal, many seeded $(12-16)$; seeds attached on retinocula, seeds flat and often incurved, compressed, translucent, size $1.4 \mathrm{~mm} \pm 0.34 \times 0.9 \mathrm{~mm} \pm 0.25$ (length $\times$ breadth), golden brown (41332) in color (Figure 5) with tumid testal surface.

\section{Anatomical Studies}

Transverse sections (hand sections) of the stem from the basal region (5.0 to $6.0 \mathrm{~cm}$ from base at maturity) and root ( 4.0 to $4.5 \mathrm{~cm}$ below base at maturity) were made from fully matured plants (at fruit ripening stage; 110-125 days from sowing), and the sections were double stained using 1.0\% Safranine (Merck, AR) dissolved in 50.0\% 
alcohol and 1.0\% Light green (Merck, AR) dissolved in $90.0 \%$ alcohol $^{54}$.

Stem (Figure 6): Tetrangular in outline; angles shortly winged with projections consisting of 1 cell layer epidermis and groups of parenchymatous cells within; shallow between ridges; thin walled compactly arranged cells cover with thin cuticle and associated with glandular hairs outside; hypodermis 2 to 5 cell layer thick, often variable in the shallow region; cells more or less rounded to polygonal, equal or larger than epidermal cells, thin, compactly arranged, containing chlorophylls; cortical layers variable, 5 to 6 cell layer thick, up to 10 below the shallow area, rounded, thin walled, compact, parenchymatous without any contents; stele amphipholic siphonostele occupying maximum part of the stem, more spreading to the ridge area; a few sclerenchymatous cell groups of 2 to 4 or even solitary throughout the periphery of the vascular bundles; outer phloem thin layered, inner phloem mostly in patches; xylem interrupted with medullary rays; pith parenchymatous, cells polygonal to rounded, larger in size, thick walled, compactly arranged, without any content.

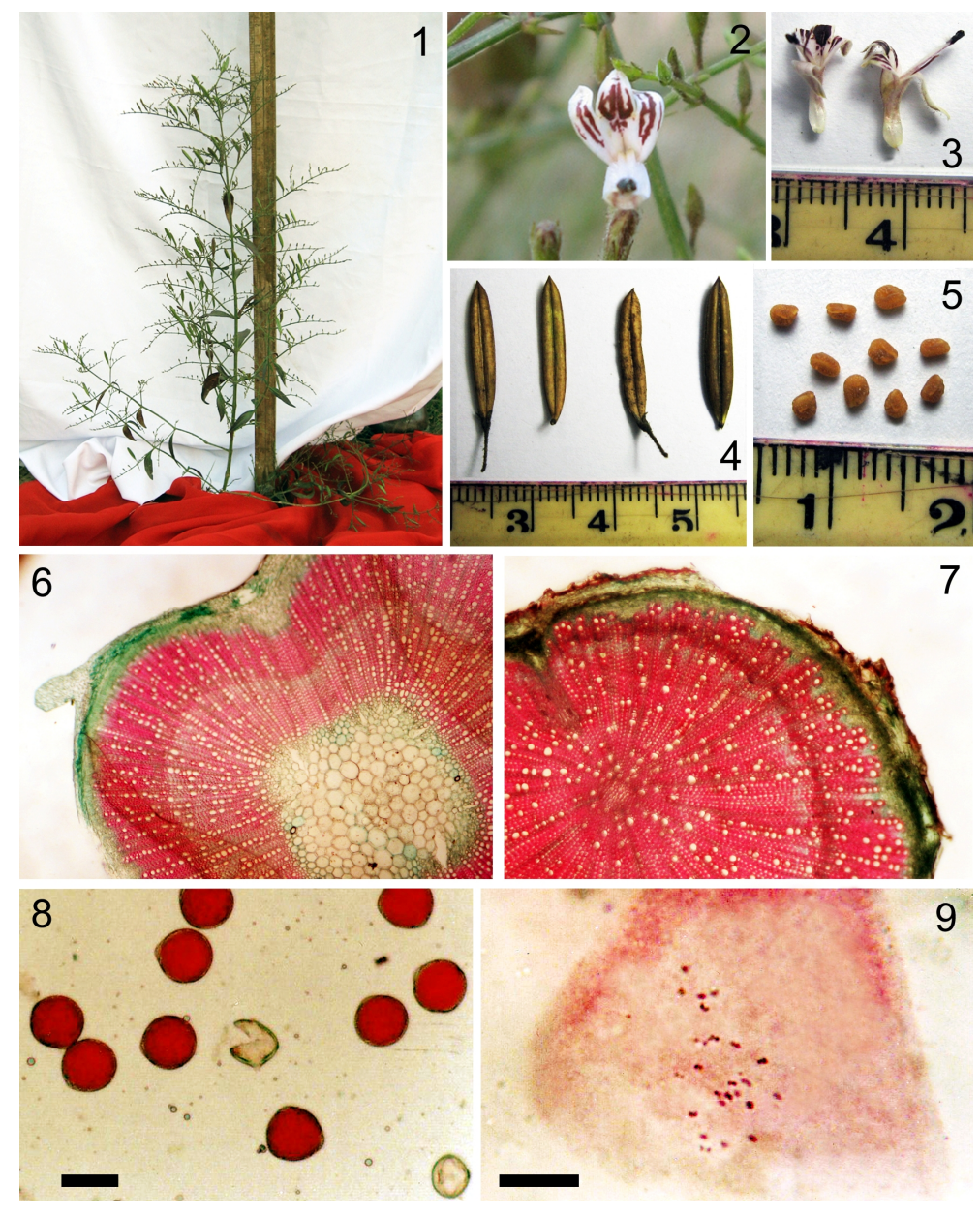

Figure 1-9: Andrographis paniculata. 1- Matured erect branched plant. 2- Flower lobes showing pigmentation. 3- Dark purple anther. 4- Fruits. 5- Golden brown seeds. 6- T.S. of stem. 7- T.S. of root. 8- Stained and unstained pollen grains (scale bar $=60 \mu \mathrm{m})$. 9- Metaphase I showing $25 \mathrm{II}(2 \mathrm{n}=\mathbf{5 0}$, scale bar $=20 \mu \mathrm{m})$.

Root (Figure 7): Secondary growth visible; epiblema not distinct replaced by cork layer, differentiated into 3 distinct zones; peripheral cell layer loosely arranged, inner cells smaller, compactly arranged; stele occupying the maximum part of the root being the secondary growth; xylem and ray cells in distinct rows, primary vascular bundle crushed; pith insignificant having few parenchymatous smaller cells.

\section{Reproductive Biology}

A. paniculata is hermaphrodite self compatible and a habitual inbreeder. Both stigma and anthers are in intimate proximity showing synchronization of anther dehiscence and stigma receptivity respectively thereby providing autonomous selfing in the species $^{42}$. The present authors analyzed number of features namely, seed set percentage on open pollination $(80.36 \pm 0.44)$ and on self pollination $(82.42 \pm 1.92)$; seed germinability in petri plates $(88.0 \%)$ and in field $(34.0 \%), 100$ seed weight (117.04 mg \pm 0.44$)$, seed moisture content (11.55\%); number of pollen grains per flower (3927.12 \pm 129.62$)$; pollen fertility $(73.68 \%$ - Figure 8 ; based on $1 \%$ acetocarmine stainability - Marks $\left.{ }^{55}\right)$; pollen size (48.26 $\mu \mathrm{m}$ to $75.8 \mu \mathrm{m}$, mean $-55.93 \mu \mathrm{m} \pm 2.62)$, number of ovules/flower (12), number of seeds/fruit (12 to 16); seed protein content $(0.065 \%)$, leaf protein content $(0.0076 \%)$, extracted as per Osborne ${ }^{56}$ and estimated following Lowry et al. ${ }^{57}$ These parameters may be useful for breeding endeavor. 


\section{Cytological Aspects}

The somatic chromosome number in A. paniculata was reported to be $2 \mathrm{n}=50^{58-64}$. Roy and Datta ${ }^{64}$ assessed different biotypes (collected from India and Bangladesh) of the species and suggested variations (chromosome length $0.50 \mu \mathrm{m}-1.75 \mu \mathrm{m}$ to $1.00 \mu \mathrm{m}-2.00 \mu \mathrm{m}$; total diploid chromosome length $-51.66 \mu \mathrm{m}$ to $70.00 \mu \mathrm{m}$ ) among the biotypes, which was attributed to minute structural aberrations like translocations, deletions, etc. Chromosomes with secondary constrictions among the biotypes ranged from 4 to 8 . The present authors analyzed meiotic chromosomes and confirmed the number as $2 \mathrm{n}=$ 50 (25 II formation at MI, 23 cells scored; $25-25$ separation of chromosomes at AI, 39 PMCs analyzed) chromosome in the species (Figure 9).

\section{Cytogenetical Study}

Lattoo et $\mathrm{al}^{42}$ induced genetic male sterility (6.0 to $14.0 \%$ ) in $A$. paniculata at $\mathrm{M}_{1}$ following $20 \mathrm{kR}$ gamma irradiation and the male sterile gene was found to be monogenic recessive to normal. The male sterile gene acted upon the tapetal layer and also affected non sporogenous tissue within the anther locule resulting in encroachment of the locule and thereby, significantly reducing the pollen production and enhancing the formation of abortive pollen. However, female fertility remained unimpaired and fully intact.

\section{Molecular Genetics}

Padmesh et al. $^{65}$ analyzed 52 accessions (displaying morphological and phytochemical variation) of $A$. paniculata from India, Thailand, Malaysia and Indonesia for intra-specific variability following RAPD analysis. Molecular analysis revealed moderate variation within the species. UPGMA followed by cluster analysis resulted in five major groups among/between genotypes and it was noted that AP-48 (Thailand) had close resemblance to AP-38 (Tamil Nadu) and AP-29 (Assam). Results indicated that RAPD could be effectively used for assessing genetic diversity and provide prospective value in breeding. Lattoo et al. ${ }^{66}$ also used RAPD (6 highly polymorphic primers) to elucidate genetic diversity among 53 accessions (varied significantly in morphometric traits) of $A$. paniculata belonging to 5 ecogeographic regions. RAPD based UPGMA and $\mathrm{D}^{2}$ cluster analysis revealed that the accessions might have originated from native places of wild abundance. The authors were of opinion that assessment of both morphometric traits and RAPD marker analysis are complementary approaches to make diversity analysis more explanatory and purposeful for optimum genetic amelioration and effective conservation of genotypic variability. On the contrary, Sakuanrungsirikul et al. ${ }^{67}$ documented that two molecular marker (ISSR-43 primers used and 391 loci detected, but monomorphic across all accessions; RAPD-41 primers used and 195 loci detected) approaches could not detect genetic variations among 44 accessions (Thailand) of the species.

\section{Extraction and detection of Phytochemicals}

Cheung et $a l .{ }^{68}$ standardized a simultaneous extraction (ethanolic), separation and detection method for andrographolides, deoxyandrographolide and neoandrographolide from the species in fused-silica capillary tube using micellar electrokinetic chromatography with UV detection at $214 \mathrm{~nm}$. Li et al. ${ }^{69}$ also standardized a quantitative HPLC method with photodiode array detection using methanolic extract of $A$. paniculata and identified the fractions as methyl, ethyl and propyl esters of $\beta$-hydroxybenzoic acid, using high resolution mass spectrophotometry and NMR. Pholphana et al. $^{70}$ proposed a rapid method for extraction and simultaneous determination of 3 active diterpenoids using isocratic HPLC with methanol and water mobile phase. This method yielded very high purity fractions from crude methanol extracts of dried leaves and stems of $A$. paniculata. Vijaykumar et al. ${ }^{71}$ also quantitated and validated andrographolide content following HPLC and HPTLC analysis.

\section{Assay}

Assay of andrographolide $\left(\mathrm{C}_{20} \mathrm{H}_{30} \mathrm{O}_{5}\right)$ can be successfully performed by extracting total andrographolide by $85 \%$ ethanol and precipitation by lead (II) acetate and following the residual titration method using $0.1 \mathrm{M} \mathrm{NaOH}$ with phenolphthalein as indicator ${ }^{72}$.

\section{Phytochemistry}

The primary medicinal component of A. paniculata is andrographolide (diterpene lactone) which is bitter in taste and colorless crystalline in appearance. Analysis of the whole plant (dry basis) yields andrographolides $\mathrm{C}_{20} \mathrm{H}_{30} \mathrm{O}_{5}$, mp $230-239^{\circ} \mathrm{C}, \quad 0.6 \%{ }^{73} ; 14-$ deoxy-11oxoandrographolide, $\mathrm{C}_{20} \mathrm{H}_{28} \mathrm{O}_{5}, \mathrm{mp} 100^{\circ} \mathrm{C}, 0.12 \%{ }^{74} ; 14-$ deoxy-11, 12-didehydroandrographolide andrographolide $\mathrm{D}, \mathrm{C}_{20} \mathrm{H}_{30} \mathrm{O}_{4}, \mathrm{mp} 203-204^{\circ} \mathrm{C}, 0.06 \%{ }^{75}$; 14-deoxyandrographolide, $\mathrm{C}_{20} \mathrm{H}_{30} \mathrm{O}_{4}, \mathrm{mp} 175^{\circ} \mathrm{C}, 0.02 \%$, and a non-bitter constituent, neoandrographolide $\mathrm{C}_{26} \mathrm{H}_{40} \mathrm{O}_{8}$, mp $167-168^{\circ} \mathrm{C}, 0.005 \%{ }^{76}$. The leaves contain the maximum amount of andrographolide $(1.0 \%$ to $2.39 \%$ ), while the seeds contain the lowest ${ }^{77}$. The leaves also possess diterpenoids (bitter principles) viz. deoxyandrographolide, 19 $\beta$-D-glucoside and neoandrographolide. The roots of the species contains apigenin - 7,4'-di-o-methyl ether, andrographolide and a new natural flavones, 5-hydroxy 7,8,2',3'-tetramethoxy flavones $\left(\mathrm{C}_{19} \mathrm{H}_{18} \mathrm{O}_{7}, \mathrm{mp} 150-151^{\circ} \mathrm{C}\right.$, yield $\left.-0.006 \%\right)$. They also contain monohydroxy trimethyl flavones, andrographin $\left(\mathrm{C}_{18} \mathrm{H}_{16} \mathrm{O}_{6}, \quad \mathrm{mp} 190-191^{\circ} \mathrm{C}\right)$ and $\mathrm{a}$ dihydroxy-di-methoxyflavone, panicolin $\left(\mathrm{C}_{17} \mathrm{H}_{4} \mathrm{O}_{6}, \mathrm{mp}\right.$ $\left.263-264^{\circ} \mathrm{C}\right)$ apart from the presence of $\alpha$-sitosterol ${ }^{78}$.

Rao et ll $^{79}$ identified two flavonoids namely, 5,7,2',3'tetramethoxyflavanone and 5-hydroxy-7,2',3'trimethoxyflavone as well as several other known flavonoids, andrographolide diterpenoids and polyphenols from the whole plant of $A$. paniculata ( $\mathrm{MeOH}$ extract was divided into $\mathrm{CHCl}_{3}, \mathrm{Me}_{2} \mathrm{CO}$ and $\mathrm{MeOH}$ soluble fractions) following spectroscopic method, including analysis by 2D NMR spectroscopy. Kulyal et al. ${ }^{80}$ reported several diterpenic constituents like andrographolide, 14-deoxy11, 12-didehydroandrographolide, 14deoxyandrographolide, 3,14-dideoxyandrographolide, 14deoxy-11-oxoandrographolide, hydroxyandrographolide, 14-deoxy-12andrographiside and 14-deoxyandrographiside from ethanolic extract of aerial parts of $A$. paniculata. The structure of the compounds were established on the basis of spectral data analysis. Xu et al. ${ }^{81}$ reported a novel 
diterpene $(13 \mathrm{R}, 14 \mathrm{R}) 3,13,14,19$-tetrahydroxy-entlabda-8(17), 11-dien-16, 15-olide 1 from ethanolic extract of leaves of the species. The structure of the compound was confirmed by X-ray crystallographic analysis.

\section{Insecticidal Activity}

Bright et ll $^{82}$ analyzed bioefficacy of different solvent fraction of $A$. paniculata against cowpea weevil (Callosobruchus chinensis L.) during post harvest storage of cowpea (Vigna unguiculata L. Walp.) in terms of adult mortality, total egg output and emergence of $F_{1}$ adults. Results indicated that adult mortality for methanolic and ethyl acetate extract were $72.01 \%$ and $67.69 \%$ respectively at the highest concentrations (1000 ppm). Total egg and percentage emergence of $F_{1}$ adults were lowest for methanolic fraction. The authors were of opinion that the principle chemical constituents of $A$. paniculata might be responsible for the mortality of the pest along with reduction in egg laying and adult emergence. Zaridah et $a l .{ }^{83}$ reported that aqueous extract of dried leaves of $A$. paniculata possess antifilarial activity when tested in vitro against adult worms of subperiodic Brugia malayi. The relative movability of the adult worms over the 24 hour observation period was taken as the index of measurement for the study. Uawonggul et al. $^{84}$ reported that extract of $A$. paniculata may be used as an antidote against scorpion (Heterometrus laoticus) venom, and the activity was measured from relative lysis of fibroblast cells.

Kuppusamy and Murugan ${ }^{1}$ reported mosquitocidal effect of $A$. paniculata (ethanolic extract of whole plant) against the malarial vector Anopheles stephensi Liston (Diptera: culicidae). The ethanolic extract of the species was found to possess larvicidal, pupicidal, adulticidal and ovicidal activities and these were attributed to the toxic impact of andrographolide, 14-deoxy-11,12didehydroandrographolides, andrographin and homoandrographolide, $19-\beta-\mathrm{D}$ glucosides, flavonoids and related compounds either singly or jointly. Elango et al. ${ }^{85}$ revealed that leaf hexane extracts of $A$. paniculata is a potent repellent ovicidal and oviposition deterrent against Culex tritaeniorhynchus (Japanese encephalitis vector).

\section{Clinical Trials}

Thamaree et. al. ${ }^{86}$ reported that A. paniculata $(500 \mathrm{mg}$ every $6 \mathrm{~h}$ and $1 \mathrm{~g}$ every $12 \mathrm{~h}$ ) can reduce both frequency and amount of defecation and also the ORS. It also effective against Shigella bacteria compared to tetracycline. Thamlikitkul et $a .^{10}$ illustrated the comparative efficacy in treatment of Pharyngotonsillitis between powder of $A$. paniculata at dosage of 3,6 and paracetamol $3 \mathrm{~g} /$ day. The results showed that the patients receiving paracetamol and powder of $A$. paniculata at 6 $\mathrm{g} /$ day recovered from pyresis and pharyngotonsillitis faster than the patients receiving only powder of $A$. paniculata. Muangman et al. ${ }^{87}$ showed that $A$. paniculata at dosage of $100 \mathrm{mg}$ three times a day showed equal efficacy as cotrimoxazole at $50 \mathrm{mg}$ twice a day or norfloxacin at $200 \mathrm{mg}$ twice a day in reduction of pus, blood or protein in urine.

Cáceres et $a l^{88}$ studied the effectiveness of dried extract (SHA-10) of $A$. paniculata in a group of 158 adults of both the sexes divided into equal groups, one of which received the extract (1200 $\mathrm{mg} /$ day) and the other a placebo during a period of five days for evaluation of symptoms like headache, tiredness, ear ache, sleeplessness, sore throat, nasal secretion and intensity of cough. Results obtained were calculated using a logistic regression model and it indicated that the dried extract of the species was much more effective in reducing the prevalence and intensity of the symptoms in uncomplicated common cold beginning at day 2 of treatment with no adverse effect.

Calabrese et $a l^{23}$ performed a phase I clinical trial of andrographolide in thirteen HIV positive patients and five uninfected volunteers (dosage administered $-5 \mathrm{mg} / \mathrm{Kg}$ to $10 \mathrm{mg} / \mathrm{Kg}$ for the first 3 weeks and $20 \mathrm{mg} / \mathrm{Kg}$ for the final 3 weeks; based on body weights, trial interrupted at 6 weeks). Results suggested that andrographolide may inhibit HIV induced cell cycle dysregulation leading to a rise in $\mathrm{CD} 4(+)$ lymphocyte levels in HIV-1 infected individuals. No change in mean plasma HIV-1 RNA levels was noted throughout the trials. Amaryan et al. ${ }^{89}$ andrographolide at $48 \mathrm{mg}$ /day was tested in patients suffered from FMF for 1 month and the results obtained showed reduction of duration, frequency and severity of symptoms in relation to abdominal or chest pain, fever, arthritis and muscle pain. Spasov et al. ${ }^{90}$ compared the efficacy of Kan Jang (herbal combination containing standardized $A$. paniculata) SHA-10 extract with Immunal, which contains Echinacea purpurea (L.) extract, in uncomplicated common cold in 130 children aged between 4 and 11 years over a period of 10 days. The effectivity of Kan Jang over Immunal was much pronounced in controlling nasal secretion and nasal congestion. Agarwal et al. ${ }^{91}$ studied adverse effects and tolerance to dry powder of aerial part of $A$. paniculata in 20 patients with type 2 diabetes mellitus for a period of 12 weeks (600 mg daily increasing gradually to $1.8 \mathrm{gm}$ daily) using parameters like body weight, blood pressure, lever function tests, renal function tests, cardiac enzymes, haemogram, serum electrolytes, fasting blood glucose, HbA1c, blood cholesterol serum triglycerides and blood hormone levels. It was noted that powdered extract of the species did not induce significant adverse effect based on the parameter studied but significantly lowered HbAlc and fasting serum insulin in patients with type 2 diabetes. Mkrtchyan et al. ${ }^{92}$ performed phase I clinical study with Kan Jang (SHA-10 extract) and standardized extract of Valeriana officinalis and Panax ginseng to evaluate the effect of semen quality of healthy males in terms of spermatogenesis. The results of the study revealed no significant negative effect of Kan Jang on male semen quality and fertility, but rather a positive trend was recorded with respect to active number of spermatozoids. The authors were of opinion that Kan Jang, ginseng and valerian were safe with respect to effect on human male sterility at three times the human daily dose. Liu et al. ${ }^{93}$ reported that oral administration of neoandrographolide $(150 \mathrm{mg} / \mathrm{Kg})$ significantly suppressed ear edema in mice; while, vascular permeability enhanced $(100-150 \mathrm{mg} / \mathrm{Kg})$. Further, in vitro studies revealed that neoandrographolide inhibits nitric oxide (NO) and tumour necrosis factor- $\alpha$ (TNF- $\alpha$ ) production in lipopolysaccharide (LPS) induced macrophages, thereby contributing to the antiinflammatory activity of $A$. paniculata. Sheeja and 
$\mathrm{Kuttan}^{94}$ reported that intraperitoneal administration of ethanolic extract of $A$. paniculata along with whole body hypothermia (WBH) enhanced the total WBC count in cyclophosphamide (CTX) and radiation treated Swiss albino mice in comparison to untreated control animals, thereby suggesting immune response capabilities of the extract. Further, it was also suggested that the elevated level of serum TNF- $\alpha$ after CTX and radiation treatment was lowered significantly after the administration of extract and simultaneous exposure of $\mathrm{WBH}$ with respect to untreated tumor bearing animals. Allan et al. ${ }^{95}$ studied the effect of andrographolide $(\geq 10.0 \%)$ on male fertility in albino Wistar rat (doses administered orally at 0,20 , 200 and $1000 \mathrm{mg} / \mathrm{kg}$ of body weight per day, for 65 days prior to mating and 21 days during mating) considering parameters like testosterone levels and fertility indices (total sperm count and sperm motility). Results suggested no adverse effect of andrographolide up to the level of consumption of $1000 \mathrm{mg} / \mathrm{kg}$ per day. Burgos et al. ${ }^{96}$ studied the effect of Paractin (tablets made from 30\% andrographolides) on 60 rheumatoid arthritis patients. The tablets were administered three times a day for 14 weeks, after a 2 week wash out period. Pain intensity was measured using a horizontal visual analogue pain scale (VAPS). Results indicated that intensity of joint pain decreased in the active vs. placebo group at the end of treatment, although not statistically significant.

\section{Contraindications and Drug Interactions}

A. paniculata has being suggested not be used during pregnancy or lactation. It is contraindicated in cases of known allergy to plants of the Acanthaceae family. Extracts of Herba Andrographidis may have a synergistic effect with isoniazid ${ }^{97}$.

\section{Clinical Implications}

Andrographolide induced DNA fragmentation and enhanced percentage of apoptotic cells in TD-47 human breast cancer cell line by increasing the expression of $\mathrm{p}^{53}$, bax, caspase -3 and concomitantly decreasing bcl-2 in a time and concentration dependent manner ${ }^{98}$. The compound also possesses anticancer activity in vitro in many tumor cell lines including leukemia, myeloma, Hela, colon (HT - 29), human peripheral blood lymphocytes (HPBLs) and human breast cancer MCF- $7^{99}$ apart from having inhibitory effect on DNA topoisomerase $\mathrm{II}^{100}$. Cell cycle inhibition by andrographolide was evidenced in human breast cancer cell (MCF-7) was due to the inhibition of the protein $\mathrm{p}^{27}$ and reduction in the expression of cyclin-dependent kinase $^{99}$.

Lin et al. ${ }^{101}$ demonstrated that ethanolic extract $(25$ $\mu \mathrm{g} / \mathrm{ml})$ of $A$. paniculata and andrographolide $(5 \mu \mathrm{g} / \mathrm{ml})$ can effectively inhibit the expression of Epstein-Barr virus lytic protein, RTA, Rta, Zta and EA-D during viral lytic cycle in P3HRI cells thereby suggesting their potentiality as an anti-EBV drug. Woo et al. (2008) revealed that the herb $A$. paniculata possesses cardioprotective activities. Andrographolide was reported to protect the cardiomyocytes against hypoxia/reoxygeneration injury and up-regulated the cellular-reduced glutathione (GSH) level and antioxidant enzyme activities in neonatal rat cardiomyocytes. The cardioprotective action of the compound was found to be completely abolished by buthionine solfoximine, which acts as a specific gamma-glutamate cysteine ligase inhibitor to deplete cellular GSH levels. Chandrasekaran et $a l^{102}$ assessed the genotoxicity of the standardized extract of the species through three different in vitro tests (Ames, chromosome aberration and micronuclei test) at different concentrations. Results of Ames test confirmed that the species did not induce mutation in Salmonela typhimurium (mutant strains TA98 and TA Mix), neither showed clustogenicity in CHO-KI cells and therefore evident that $A$. paniculata is genotoxically safe. Chao et $a l .{ }^{103}$ reported that ethyl acetate extract of $A$. paniculata significantly inhibited NF- $\kappa \beta$ luciferase activity and TNF$\alpha$, interleukin 6 (IL-6), macrophage inflammatory protein2 (MIP-2) and nitric oxide secretion from LPS/interferon$\gamma$ stimulated Raw 264.7 cells. Pekthong et al. ${ }^{104}$ studied the ability of $A$. paniculata extract ( 0.5 and $2.5 \mathrm{~g} / \mathrm{kg} /$ day) on the expression of cytochrome P450 (CYP) both in vivo in rats and in vitro in rat and human hepatocyte cultures. The authors concluded from the experiments that both herbal extract and andrographolide can modulate the expression and activities of CYP2C9 and CYP3A4.

\section{Regulatory Mechanism}

Smith et al. ${ }^{105}$ identified an active compound bisandrographolide A (BAA) from standardized extract of A. paniculata and it was found to potentially activate TRPV4 (transient receptor potential) channel (but not TRPV1, TRPV2 and TRPV3) with an $\mathrm{EC}_{50}$ of 790 to 950 $\mathrm{nm}$ following Ca-imaging assay. It is noteworthy to mention that TRPV4 is a non selective cation channel and its activation causes opening of a pore that allows $\mathrm{Na}^{+}, \mathrm{K}^{+}$ and $\mathrm{Ca}^{2+}$ ions to cross membrane. Thus, the resulting increase in internal free $\mathrm{Ca}^{2+}$ and changes in transmembrane voltage potentiality can affect cell signaling apart from its implications in osmoregulation, regulation of vascular tone and heat sensation. Jarukamjorn $^{106}$ reported the inductive effect of andrographolide on transcriptional regulatory mechanism by increasing hepatic CYP1A (Cytochrome P450 - role in transcriptional regulation has been postulated through arylhydrocarbon receptor, AhR and AhR nuclear translocator) enzymes including ethoxyresorufin and methoxyresorufin activities.

\section{In vitro Studies}

Martin $^{107}$ studied in vitro propagation of $A$. paniculata through somatic embryogenesis and also analyzed the influence of 2,4-dichlorophenoxy acetic acid (2,4-D) on induction, maturation and conversion of somatic embryos. Friable callus was initiated using leaf and internode explants in MS medium supplemented with various concentrations of 2,4-D. Embryos formed from 105 to 185 days after explant establishment, wherein callus subcultured on reduced 2,4-D concentration $(2.2 \mu \mathrm{M}$ and $1 / 2 \mathrm{MS}$ - liquid media) gave rise to highest number of embryos (mean of 312 ) of which $71 \%$ of the embryos underwent maturation out of those $83 \%$ developed into plantlets and $88 \%$ of the plantlets survived under field condition. Praveen et al. ${ }^{108}$ induced adventitious roots directly from leaf segment of $A$. paniculata on MS medium with $5.3 \mu \mathrm{M} \alpha$-napthaleneacetic acid (NAA) and $30 \mathrm{gm} / 1$ sucrose and highlighted the great potentiality of 
adventitious root cultures for the production of andrographolide.

\section{Mutational Studies}

Ghosh et al. ${ }^{109}$ screened 14 viable macromutants (viridis, lax branching, bushy, unbranched I and II, dark green leaf, broad leaf I and II, narrow leaf $I$ and $I I$, drooping leaf $I$ and $I I$, dwarf and early maturity) at $\mathrm{M}_{2}$ following EMS and dES treatments. Mutation frequency over $\mathrm{M}_{2}$ population was $2.82 \%$ and lax branching mutant was maximum (0.51\%).EMS induced relatively higher $(3.12 \%)$ frequency of mutation than $\mathrm{dES}(2.46 \%)$. The mutant traits were monogenic recessive mostly (viridis showed digenic mode of inheritance). All mutants bred true in $M_{4}$ generation. Meiotic analysis revealed $2 n=50$ chromosome in mutants alike to control. Andrographolide (estimated from matured leaves by HPTLC) content (control: 3.41\%, mutants: 0.03 to $3.99 \%$ ) was significantly higher in bushy and broad leaf I and II than normal plants. The mutants induced were considered to be important genetic resources in the plant species.

\section{CONCLUSION}

Unabridged repository of references has been provided in the text in relation to the comprehensive overview on $A$. paniculata with an objective to update researchers with adequate information for its effective exploration for human benefit.

\section{REFERENCES}

1. Kuppusamy C, Murugan K. Effects of Andrographis paniculata Nees on growth, development and reproduction of malarial vector Anopheles stephensi Liston (Diptera: Culicidae). Trop Biomed 2008; 27:509-16.

2. Hancharnlerd O, Babprasert C, Phisuksanthiwattana Y. Medicinal Plants in Pakchong Research Station Garden. Faculty of Agriculture. Kasetsart Univ. Thailand; 1994.

3. Bobbarala V, Katikala PK, Naidu KC, Penumajji S. Antifungal activity of selected plants extracts against phytopathogenic fungi Aspergillus niger. Indian J Sci Technol 2009; 20(4):87-90.

4. Puri A, Saxena R, Saxena RP, Saxena KC, Srivastava V, et al. Immunostimulant agents from Andrographis paniculata. J Nat Prod 1993; 56:995-9. $\quad$ http://dx.doi.org/10.1021/np50097a002 PMid:8377022

5. Rao MR. Flowering Plants of Travancore. Bishen Singh Mahendra Pal Singh: The University of California; 1914. p. 307-8.

6. Bhalla NP, Sahu TR, Mishra GP, Dakwale RN. Traditional plant medicines of Sagar district, Madhya Pradesh, India. J Econ Tax Bot 1982; 3:23-32.

7. Vohora SB. What is purification of blood? Hamdard 1985; 28:72 84.

8. Dey KL. The Indigenous Drugs of India (II Ed). Pama Primlane the Chronica Botanica: New Delhi; 1986.

9. Gupta S, Choudhary MA, Yadava JNS, Srivastava V, Tandon JS. Antidiarrhoeal activity of diterpenes of Andrographis paniculata (Kalmegh) against Escherichia coli enterotoxin in in vivo models. Int J of Crude Drug Res 1990; 28:273-83.

10. Thamlikitkul V, Dechatiwongse T, Theerapong S. Efficacy of Andrographis paniculata, Nees for pharyngotonsillitis in adults. J Med Assoc Thai1991; 74(10):437-42. PMid:1797953

11. Ahmad M, Asmawi M. A study of the hypoglycaemic property of Andrographis paniculata Nees. 7th Asian Symposium on Med Plants, Spices and other Natural Prod (ASOMPS VII): Manila; 1992.

12. Home C, Roy L, Roy A. Management of khalitya (Alopecia areata) by Ayurvedic approach. Int Sem on Traditional Medicine: Calcutta; 1992. p. 124.

13. Gupta V, Srivastava VK. Kalmegh- from ethnobotanical realm to modern medication. IV Int Cong Ethnobiol, NBRI, Lucknow; 1994.

14. Guo Z, Zhao H, Zheng X. An experimental study of the mechanism of Andrographis paniculata nees (APN) in alleviating the $\mathrm{Ca}^{2+}$ - overloading in the process of myocardial ischemic reperfusion. $\mathrm{J}$ Tongji Med Univ 1995; 15:205-8. $\underline{\text { http://dx.doi.org/ }}$ 10.1007/BF02887945 PMid:8731924

15. Melchior J, Palm S, Wikman G. Controlled clinical study of standardized Andrographis paniculata extract in common cold-a pilot trial. Phytomed 1996; 34:315-8. http://dx.doi.org/ 10.1016/S0944-7113(97)80002-5

16. Zhang XF, Tan BK. Antihyperglycaemic and anti-oxidant properties of Andrographis paniculata in normal and diabetic rats. Clin Exp Pharmacol Physiol 2000; 27:358-63. http://dx.doi.org/ 10.1046/j.1440-1681.2000.03253.x PMid:10831236

17. Coon JT, Ernst E. Andrographis paniculata in the treatment of upper respiratory tract infections: a systematic review of safety and efficacy. Planta Med 2004; 70(4):293-8. http://dx.doi.org/10.1055/s2004-818938 PMid:15095142

18. Tomar GS, Tiwari SK, Chaturvedi GN. Treatment of jaundice (Kamla) with Andrographis paniculata Nees (Kalmegh). Proc Asian Conf on Traditional Asian Med: Bombay; 1983.

19. Viswanathan SP, Kulanthaivel SK, Nazimudeen T, Vinayakam C, Gopalakrishnan et al. The effect of apigenin 7,4'-di-O-methyl ether, a flavon from Andrographis paniculata on experimentally induced ulcers. Ind J Pharm Sci 1981; 43:159-61.

20. Anonymous. The Wealth of India: Raw Materials. Vol. IA, Council of Scientific and Industrial Research, New Delhi; 1985.

21. Selvanayagam ZE, Gnanavendhan SG, Chandrasekharan P, Balakrishna K, Rao RB. Plants with antisnakevenom activity - a review on pharmacological and clinical studies. Fitoterapia 1994; 65:99-111.

22. Amroyan E, Gabrielian E, Panossian A. Inhibitory effect of andrographolide from Andrographis paniculata on PAF-induced platelet aggregation. Phytomed 1999; 6(1):27-31. http://dx.doi.org/ 10.1016/S0944-7113(99)80031-2

23. Calabrese C, Berman SH, Babish JG, Ma X, Shinto L, et al. A phase I trial of andrographolide in HIV positive patients and normal volunteers. Phytother Res 2000; 14:333-8. http://dx.doi.org/ 10.1002/1099-1573(200008)14:5<333::AID-PTR584>3.0.CO;2-D

24. Dua VK, Ojha VP, Roy R. Anti-malarial activity of some xanthones isolated from the roots of Andrographis paniculata. J Ethnopharmacol 2000; 95(2-3):247-51. http://dx.doi.org/ 10.1016/j.jep.2004.07.008

25. Akbarsha MA, Murugaian P. Aspects of the male reproductive toxicity/male antifertility property of andrographolide in albino rats: effect on the testis and the cauda epididymidal spermatozoa. Phytother Res 2000; 14:432-5. http://dx.doi.org/10.1002/10991573(200009)14:6<432::AID-PTR622>3.0.CO;2-I

26. Shen YC, Chen CF, Chiou WF. Andrographolide prevents oxygen radical production by human neutrophils: possible mechanism(s) involved in its anti-inflammatory effect. $\mathrm{Br} \mathrm{J}$ Pharmacol 2002; 135(2):399-406. http://dx.doi.org/ 10.1038/sj.bjp.0704493 PMid:11815375 PMCid:1573154

27. Rao NK. Anti hyperglycemic and renal protective activities of Andrographis paniculata roots chloroform extract. Iranian $\mathrm{J}$ Pharmacol Ther 2006; 5(1):47-50.

28. George M, Pandalai KM. Investigations on plant antibiotics part IV. further search for antibiotic substances in Indian medicinal plants. Indian J Med Res 1949; 37:169-81.

29. Nakanishi K. Phytochemical surveyof Malaysian plants: Preliminary chemical and pharmacological screening. Chem Pharmaceut Bull 1965; 13:882-90. $\underline{\text { http://dx.doi.org/ }}$ $\underline{10.1248 / \mathrm{cpb} .13 .882}$

30. Komwatchara T. The development of Andrographis paniculata extract gel for microbial inhibition in adult periodontitis. M.Sc. Thesis, Graduate School, Mahidol University. Bangkok: Thailand; 1996.

31. Rassameemasmaung S. Subgingival administration of Andrographis paniculata gel as an adjunct in the treatment of adult periodontitis. M.Sc. Thesis, Graduate School, Mahidol University. Bangkok: Thailand; 1996.

32. Prajjal K, Singha S, Roy, Dey S. Antimicrobial activity of Andrographis paniculata, Fitoterapia 2003; 74(7-8):692-4. http://dx.doi.org/10.1016/S0367-326X(03)00159-X

33. Roy S, Rao K, Bhuvaneswari C, Giri A, Mangamoori LN. Phytochemical analysis of Andrographis paniculata extract and its antimicrobial activity. World J Microbiol Biotechnol 2010; 26:8591. http://dx.doi.org/10.1007/s11274-009-0146-8

34. DMPRD (Division of Medical Plants Research and Development, Department of Medical Science, Ministry of Public Health). 
Handbook of Medicinal Plant for Primary Public Health. Text and Journal Corporation Co., Ltd. Press: Bangkok; 1990. p. 53.

35. Hooker JD. "Flora of British India". Reeve \& CO. LTD. Ashford, Kent. IV; 1885.

36. Hsu HY. Oriental Materia Medica: A Concise Guide. Long Beach, CA, Oriental Healing Arts Institute; 1986.

37. Chang HM, But PPH, eds. Pharmacology and Applications of Chinese Materia Medica. Vol. 1. Singapore, World Scientific; 1986:918-928.

38. Kapoor LD. CRC Handbook of Ayurvedic Medicinal Plants. Boca Raton, FL:CRC Press; 1990. p.39.

39. Maunwongyathi P. Next Step of Medicinal Plant. Medical media Prees.Bangkok-noi: Bangkok, Thailand; 1994.

40. Ruengrungsri N, Tuntiwat P. Medicinal Plant. Odient Store Press.Bangkok: Thailand; 1994.

41. Farnsworth NF, ed. NAPRALERT database. Chicago, University of Illinois at Chicago, IL, January 28, 1998 production (an online database available directly through the University of Illinois at Chicago or through the Scientific and Technical Network [STN] of Chemical Abstracts Services).

42. Lattoo SK, Khan S, Dhar AK, Choudhary DK, Gupta KK et al. Genetic and mechanism of induced male sterility in Andrographis paniculata (Burm. f.) Nees and its significance. Curr Sci 2006; 9(4):515-9.

43. Zhou Z. Cultivation of Andrographis paniculata. Chung Yao Tung Pao 1987; 12:15-8. PMid:3446398

44. Muniramappa RP, Farooqi AA, Gowda HGR, Maricapu S Influence of macronutrients on yield and active principle content in Kalmegh. J Med Arom Plant Sci 1997; 19:1039-42.

45. Samantaray S, Rout GR, Das P. Heavy metal and nutrient concentration in soil and plants growing on a metalliferous chromite minespoil. Enviro Tech 2001; 22:1147-54. http://dx.doi.org/ 10.1080/09593332208618204

46. Kasetklangklung. Andrographis paniculata, Thai medicinal plant. J Transfer Tech Agri 1996; 2(14):6-17.

47. MPRI (Medicinal Plant Research Institute, Department of Medical Science, Ministry of Public Health). Standard of Thai Herbal Medicine: Andrographis paniculata (Burm. f.) Nees. The War Veterans Organization Press: Bangkok, Thailand; 1999.

48. Vijaya D, Padmadevi SN, Vasandha S, Meerabhai RS, Chellapandi P. Effect of vermicomposted coirpith on the growth of Andrographis paniculata. J Org Syst 2008; 3(2):51-6.

49. Nandi RP. Increase in productivity regime of some well known medicinal and aromatic plants used in Ayurvedic system of medicines. Adv Plant Sci 1992; 5:274-82.

50. Gupta V, Srivastava VK. Evaluation studies on Kalmegh (Andrographis paniculata Nees). Ind J Pl Genet Resour 1995; 8:141-3.

51. Anonymous. The BIOME News. Vol 1 (2). J. R. Arora, Renu Swarup and S. V. Gupta (eds.). Dept of Biotechnology, Ministry of Science and Technology, Govt of India; 2000.

52. Tipakorn N. Effects of Andrographis paniculata (Burm.F.) Nees on performance, mortality and coccidiosis in broiler chickens. Ph.D. thesis. Institute of Animal Physiology and Animal Nutrition, GeorgAugust-Universitat, Gottingen; 2002.

53. Plubrukarn A, Pinsuwan S, Ingkatawornwong S, Supavita $T$. Stability of andrographolide in powdered Andrographis herb under accelerated conditions. Planta Med 2006; 72(10):954-6 http://dx.doi.org/10.1055/s-2006-946696 PMid:16902869.

54. Johansen DA. Plant Microtechnique. McGraw-Hill Book Company Inc.: New York; 1940.

55. Marks GE. An aceto-carmine glycerol jelly for using pollen-fertility counts. Stain Technol 1954; 29:277. http://dx.doi.org $/ 10.3109 / 10520295409115483$

56. Osborne TB. The Vegetable Proteins. 2nd Edn., Congmans, Green and Co.: London; 1924.

57. Lowry $\mathrm{OH}$, Rosebrough NJ, Farr AL, Randall RJ. Protein measurement with the Folin phenol reagent. J Biol Chem 1951; 193:265-75. PMid:14907713

58. Raghavan. Chromosome atlas of flowering plants of the Indian subcontinent; p 1 ed. Kumar V and Subramaniam B (Calcutta, India: Botanical Survey of India); 1957.

59. Ellis JL. Chromosome numbers in some members of Acanthaceae. Sci Cult 1962; 28:191-2.

60. Mitra K, Datta N. Cited in: IOPB chromosome number reports VIII. Taxon 1967; 16:445-61.
61. Fedorov AA. Chromosome number of flowering plants. Acad Sci, U.S.S.R.: 1969. p. 926.

62. Datta PC, Maiti RK. Relationships of Justicieae (Acanthaceae) based on cytology. Genetica 1970; 41:437-50. http://dx.doi.org/ 10.1007/BF00958924

63. Govindarajan T, Subramanian D. Karyomorphological studies in south Indian Acanthaceae. Cytologia 1983.; 8:491-504. http://dx.doi.org/10.1508/cytologia.48.491

64. Roy SK, Datta PC. Chromosomal Biotypes of Andrographis paniculata in India and Bangladesh. Cytologia 1988; 53:369-78. http://dx.doi.org/10.1508/cytologia.53.369

65. Padmesh P, Sabu KK, Seeni S, Pushpangadan P. The use of RAPD in detecting genetic variability in Andrographis paniculata Nees: a potent hepatoprotective drug. Curr Sci 1998; 76:833-5.

66. Lattoo SK, Dhar RS, Khan S, Bamotra S, Bhan MK et al. Comparative analysis of genetic diversity using molecular and morphometric markers in Andrographis paniculata (Burm. f.) Nees. Genet Resour Crop Evol 2008; 55:33-43. http://dx.doi.org/ 10.1007/s10722-007-9212-y

67. Sakuanrungsirikul S, Jetana A, Buddanoi P, Dithachaiyawong J. Intraspecific variability assessment of Andrographis paniculata collections using molecular markers. In: Chomchalow, N. and Chantrasmi, V. (eds) Acta Hortculturae 786: International Workshop on Medicinal and Aromatic Plants, Chiang Mai, Thailand, ISHS; 2008. pp. 283-6.

68. Cheung HY, Cheung CS, Kong CK. Determination of bioactive diterpenoids from Andrographis paniculata by micellar electrokinetic chromatography. J Chromatogr A 2001; 930:171-6. http://dx.doi.org/10.1016/S0021-9673(01)01160-8

69. Li W, Sun Y, Joseph J, Fitzloff JF, Fong HHS et al. pHydroxybenzoic acid alkyl esters in Andrographis paniculata herbs, commercial extracts, and formulated products. J Agr Food Chem 2003; 51(2):524-9. http://dx.doi.org/10.1021/jf0258712

70. Pholphana N, Rangkadilok N, Thongnest S, Ruchirawat S, Ruchirawat $\mathrm{M}$, et al. Determination and variation of three active diterpenoids in Andrographis paniculata (Burm.f.) Nees. Phytochem Anal 2004; 15(6):365-71. http://dx.doi.org/ 10.1002/pca.789 PMid:15595451

71. Vijaykumar K, Murthy PBS, Kannababu S, Syamasundar B, Subbaraju GV. Estimation of andrographolide in Andrographis paniculata herb, extacts and dosage forms. Int J Appl Sci Eng 2007; 5:27-39.

72. Saohin W, Boonchoong P, Iamlikitkuakoon S, Jamnoiprom I, Mungdee W. Effects of drying temperature and residual moisture content of Fa-Tha-Li (Andrographis paniculata (Burm.f.) Nees) crude powder for capsule preparation. Thai J Pharm Sci 2007; 31:28-35.

73. Gorter MK. The bitter constituent of Andrographis paniculata Nees. Rec Trav Chim 1911; 30:151-60.

74. Saraswat B, Visan PKS, Patnai GK, Dhawan BN. Effect of andrographolide against galactosamine induced hepatotoxicity. Fitoterapia 1995; 66:415-20.

75. Visen PKS, Shukla B, Patnaik GK, Dhawan BN. Andrographolide protects rat hepatocytes against paracetamol-induced damage. J Ethnopharmacol 1993; 40:131-6. http://dx.doi.org/10.1016/03788741(93)90058-D

76. Chao WW, Lin BF. Isolation and identification of bioactive compounds in Andrographis paniculata (Chuanxinlian). Chin Med [Article Number 17]. 2010; 5:17. 10.1186/1749-8546-5-17

77. Sharma A, Lai K, Handa SS. Standardization of Indian crude drug kalmegh by highperformance liquid chromatographic determination of andrographolide. Phytochem Anal 1992; 3(3):129-31. http://dx.doi.org/10.1002/pca.2800030308

78. Saxena S, Jain DC, Bakhuni RS, Sharma RS. Chemistry and pharmacology of Andrographis species. Indian Drugs 1998; 35:45867.

79. Rao YK, Vimalamma G, Rao CV, Tzeng YM. Flavonoids and andrographolides from Andrographis paniculata. Phytochem 2004; 65:2317-21. http://dx.doi.org/10.1016/j.phytochem.2004.05.008

80. Kulyal P, Tiwari UK, Shukla A, Gaur AK. Chemical constituents isolated from Andrographis paniculata. Indian J Chem 2010; 49B:356-9.

81. Xu C, Chou GX, Wang ZT. A new diterpene from the leaves of Andrographis paniculata Nees. Fitoterapia 2010; 81(6):610-3. http://dx.doi.org/10.1016/j.fitote.2010.03.003

82. Bright AA, Babu A, Ignacimuth S, Dorn S. Efficacy of crude extracts of Andrographis paniculata nees. on Callosobruchus 
chinensis L. during post harvest storage of cowpea. Indian J Exp Biol 2001; 39:715-8. PMid:12019768

83. Zaridah MZ, Idid SZ, Omar AW, Khozirah S. In vitro antifilarial effects of three plant species against adult worms of subperiodic Brugia malayi. J Ethnopharmacol 2001; 78:79-84. http://dx.doi.org/ 10.1016/S0378-8741(01)00286-0

84. Uawonggul N, Chaveerach A, Thammasirirak S, Arkaravichien T, Chuachan $\mathrm{C}$, et al. Screening of plants acting against Heterometrus laoticus scorpion venom activity on fibroblast cell lysis. J Ethnopharmacol 2006; 103:201-7. $\quad$ http://dx.doi.org/10.1016 /j.jep.2005.08.003

85. Elango G, Rahuman AA, Kamaraj C, Zahir AA, Bagavan A Studies on effects of indigenous plant extracts on filarial vector Culex tritaeniorhynchus Giles. Parasitol Res 2010; 107:167-76. http://dx.doi.org/10.1007/s00436-010-1856-4

86. Thamaree S, Pachotikarn C, Tankeyoon M, Itthipanichpong C. Effect on intestinal motility of thirty herbal medicines used in treatment of diarrhoea and dysentery. Chula Med J 1985; 29:9-51.

87. Muangman V, Viseshsindh V, Ratana-Olarn K, Buadilok S. The usage of Andrographis paniculata following extracorporeal shock wave lithotripsy (ESWL). J Med Assoc Thai 1995; 78:310-3. PMid:7561556

88. Cáceres DD, Hancke JL, Burgos RA, Sandberg F, Wikman GK. Use of visual analogue scale measurements (VAS) to assess the effectiveness of standardized Andrographis paniculata extract SHA-10 in reducing the symptoms of common cold. A randomized double blind-placebo study. Phytomed 1999; 6:217-23. http://dx.doi.org/10.1016/S0944-7113(99)80012-9

89. Amaryan G, Astvatsatryan V, Gabrielyan E, Panossian A, Panosyan $\mathrm{V}$, et al. Double-blinding, placebo-controlled, randomized, pilo clinical trial of Immuno Guard-a standardized fixed combination of Andrographis paniculata Nees, with Eleutherococcus senticosus Maxim, Schizandra chinensis Bail. and Glycyrrhiza glabra L. extract in patients with Familial Mediterranean Fever. Phytomed 2003; 10(4):271-85. http://dx.doi.org/10.1078/ 094471103322004767

90. Spasov AA, Ostrovskij OV, Chernikov MV, Wikman G. Comparative controlled study of Andrographis paniculata fixed combination, Kan Jang and an Echinacea preparation as adjuvant, in the treatment of uncomplicated respiratory disease in children Phytother Res 2004; 18(1):47-53. http://dx.doi.org/10.1002/ptr.1359

91. Agarwal R, Sulaiman SA, Mohamed M. Open label clinical trial to study adverse effects and tolerance to dry powder of the aerial part of Andrographis paniculata in patients type 2 with diabetes mellitus. Malays J Med Sci 2005; 12(1):13-9. PMid:22605942 PMCid:3349408

92. Mkrtchyan A, Panosyan V, Panossian A, Wikman G, Wagner H. A phase I clinical study of Andrographis paniculata fixed combination Kan Jang versus ginseng and valerian on the semen quality of healthy male subjects. Phytomed 2005; 12(6-7):403-9. http://dx.doi.org/10.1016/j.phymed.2004.10.004

93. Liu J, Wang ZT, Ji LL. In vivo and in vitro anti-inflammatory activities of neoandrographolide. Am J Chinese Med 2007; 35(2):317-28. http://dx.doi.org/10.1142/S0192415X07004849 PMid: 17436371

94. Sheeja K, Kuttan G. Ameliorating effects of Andrographis paniculata extract against cyclophosphamide-induced toxicity in mice. Asian Pac J Cancer Prev 2008; 7(4):609-14.

95. Allan JJ, Pore MP, Deepak M, Murali B, Mayachari AS, et al. Reproductive and fertility effects of an extract of Andrographis paniculata in male Wistar rats. Int J Toxicol 2009; 28:308-17. http://dx.doi.org/10.1177/1091581809339631 PMid:19636073
96. Burgos RA, Hancke JL, Bertoglio JC, Aguirre V, Arriagada S, et al. Efficacy of an Andrographis paniculata composition for the relief of rheumatoid arthritis symptoms: a prospective randomized placebo-controlled trial. Clin Rheumatol 2009; 28(8):931-46. http://dx.doi.org/10.1007/s10067-009-1180-5

97. Anonymous. Beijing Medical College, Physiology Department: Experimental observation on the termination of pregnancy by the Andrographis herb (Andrographis paniculata N.). Acta Physiol Sin 1978; 30(10):75-80.

98. Harjotaruno S, Widyawaruyanti A, Sismindari, Zaini NC. Apoptosis inducing effect of andrographolide on td-47 human breast cancer cell line. Afr J Tradit Complem 2007; 4:345-51.

99. Satyanarayana C, Dhanavanthri SD, Rajagopalan R, Nanduri S, Sriram R. DRF 3188 a novel semi synthetic analog of andrographolide: cellular response to MCF 7 breast cancer cells. BMC Cancer 2004; 4(26):1-8. http://dx.doi.org/10.1186/1471-2407$\underline{4-26}$

100.Sukardiman S, Zaini NC. Anticancer activity of pinostrobin and andrographolide. Proceeding of Congress of Pharmaceutical Future, Tokyo, Japan; 2005

101.Lin TP, Chen SY, Duh PD, Chang LK, Liu YN. Inhibition of the epstein-barr virus lytic cycle by andrographolide. Biol Pharm Bull 2008; 31(11):2018-23. http://dx.doi.org/10.1248/bpb.31.2018

102.Chandrasekaran CV, Thiyagarajan P, Sundarajan K, Goudar KS, Deepak M, et al. Evaluation of the genotoxic potential and acute oral toxicity of standardized extract of Andrographis paniculata (KalmCold). Food Chem Toxicol 2009; 47(8):1892-902. http://dx.doi.org/10.1016/i.fct.2009.05.006

103. Chao WW, Kuo YH, Hsieh SL, Lin BF. Inhibitory effects of ethyl acetate extract of Andrographis paniculata on NF- $\kappa \mathrm{B}$ transactivation activity and LPS-induced acute inflammation in mice. $\mathrm{J}$ Evid Based Complementary Altern Med 2011; 9 pages. http://dx.doi.org/10.1093/ecam/nep120

104.Pekthong D, Blanchard N, Abadie C, Bonet A, Heyd B, et al. Effects of Andrographis paniculata extract and andrographolide on hepatic cytochrome P450 mRNA expression and monooxygenase activities after in vivo administration to rats and in vitro in rat and human hepatocyte cultures. Chem Biol Interact 2009; 179(2-3):24755. http://dx.doi.org/10.1016/i.cbi.2008.10.054

105.Smith PL, Maloney KN, Pothen RG, Clardy J, Clapham DE. Bisandrographolide from Andrographis paniculata activates TRPV4 channels. J Biol Chem 2006; 281(40):29897-904. http://dx.doi.org/10.1074/jbc.M605394200

106.Jarukamjorn K. Andrographis paniculata: a review of aspects of regulatory mechanisms of hepatic CYP1A enzymes. Bol Latinoam Caribe Plant Med Aromat 2008; 7(2):100-7.

107.Martin KP. Plant regeneration protocol of medicinally important Andrographis paniculata (Burm. F.) Wallich ex Nees via somatic embryogenesis. In Vitro Cell Dev-P1 2004; 40(2):204-9.

108.Praveen N, Manohar SH, Naik PM, Nayeem A, Jeong JH, et al. Production of andrographolide from adventitious root cultures of Andrographis paniculata. Curr Sci 2009; 96:694-7.

109.Ghosh BK, Datta AK, Das A, Mandal A. Induced macromutation in Andrographis paniculata (Burm. F.) Nees. Int J Res Ayur Pharm 2012; 3(4):604-10.

\section{Cite this article as:}

Ghosh Kumar Benoy, Datta Kumar Animesh, Mandal Aninda, Dubey Kumari Priyanka and Halder Sandip. An overview on Andrographis paniculata (Burm. F.) Nees. Int. J. Res. Ayur. Pharm. 2012; 3(6):752760 